\section{Drainage network reorganization and aridification in "EI Desierto de la Tatacoa" (Colombia) in the Late Pleistocene}

\section{DANIEL H SOUZA ${ }^{1}$, MAURICIO PARRA ${ }^{2}$, FABIANO PUPIM $^{3}$ AND IAN DEL RIO 4}

${ }^{1}$ Institute of Energy and Environment - University of São Paulo

${ }^{2}$ Institute of Energy and Environment - University of Sao Paulo

${ }^{3}$ Federal University of São Paulo

${ }^{4}$ University of São Paulo

Presenting Author: danielhsouza@usp.br

'El Desierto de la Tatacoa' lies at $\sim 3.2^{\circ} \mathrm{N}$ Lat in the Upper Magdalena Valley, a Cenozoic intermontane Basin between Central and Eastern Cordillera in the Andes of Southern Colombia. Mean annual temperatures of $27^{\circ} \mathrm{C}$ and precipitation of $1300 \mathrm{~mm}$ allow the development of savanna vegetation. Despite this climatic condition, the sparse vegetation in Tatacoa resembles a semi-arid environment (Fig.1). Based on optically stimulated luminescence dating in two fluvial terraces, we propose that such aridification occurred due to drainage network reorganization during the late Pleistocene. Currently, no river coming from the Eastern Cordillera drains into Magdalena River in Tatacoa area. This makes the Tatacoa rivers unable to balance the evapotranspiration effect on discharge, causing a surficial hydric deficit (Fig.2). A fluvial terrace (TAT-2) works as a divide between Cabrera (a high order Eastern Cordillera river) and the Tatacoa catchments. Such terrace lies $200 \mathrm{~m}$ above the Cabrera River and is composed by 4 to 10 meters of metasedimentary clasts. Paleocurrent measurements on these clasts point to a W-NW flow into the Magdalena; this is the same direction as the Cabrera before it shifts to north when approaches TAT-2 (Fig.2). Thus, OSL ages of $74.6 \pm 6.1 \mathrm{ka}$ and $52.4 \pm 9.5$ $\mathrm{ka}$ in this terrace suggest the Tatacoa was drained by an Eastern Mountain river during Late Pleistocene. At the western end of Tatacoa, terraces (TAT-1) $80 \mathrm{~m}$ above Magdalena River have ages of $10.7 \pm 2.1$ and $17.8 \pm 3.3 \mathrm{ka}$. Between both terraces, the Tatacoa catchments mimic the Cabrera river and shift northwards to reach the Magdalena, leading to the isolation of the Magdalena floodplain from part of the desert. Thus, the northward shift of the Cabrera River and the westward migration of the Magdalena valley floor have drastically reduced the surficial water availability in Tatacoa. Potential climatic and tectonic drivers include terrace abandonment after dry periods; incision of the Magdalena river along the Prado fault (N-NW desert limit), which would have attracted tributaries such as the Cabrera River; and activity on Baraya thrust fault which would have prevented small rivers from the Eastern Cordillera to entry the desert.

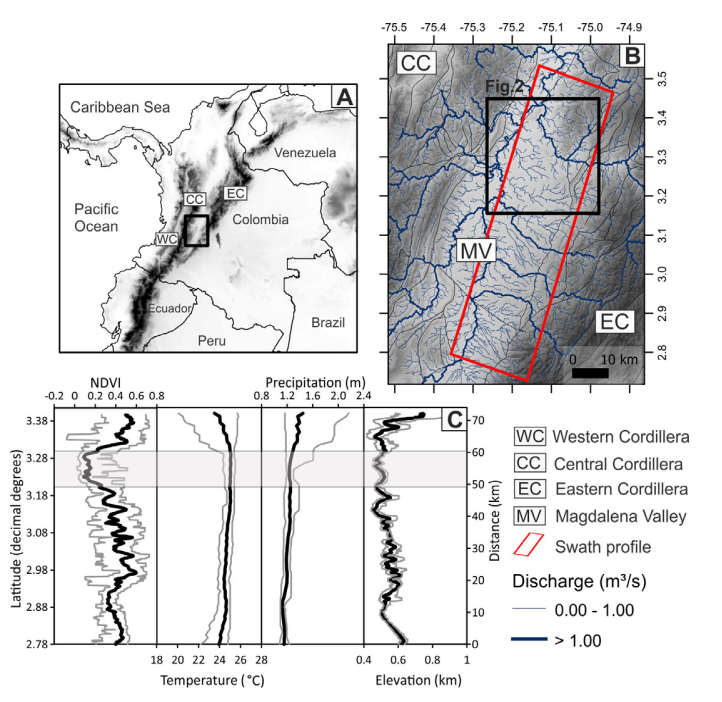

Figure 1. A. Location of the Study area within NW South America; B. The Upper Magdalena valley and the $20 \mathrm{~km}$ wide swath profile location; C. Latitudinal variation of vegetation (NDVI index - from Sentinel2 images), mean annual temperature, mean annual precipitation (https://chelsa-climate.org/bioclim/) and elevation across the Upper Magdalena Valley. The thick black lines indicate the mean values across the swath profile; the grey lines correspond to minimum and maximum values. The Tatacoa Desert is
highlighted by the grey box the on the graph.

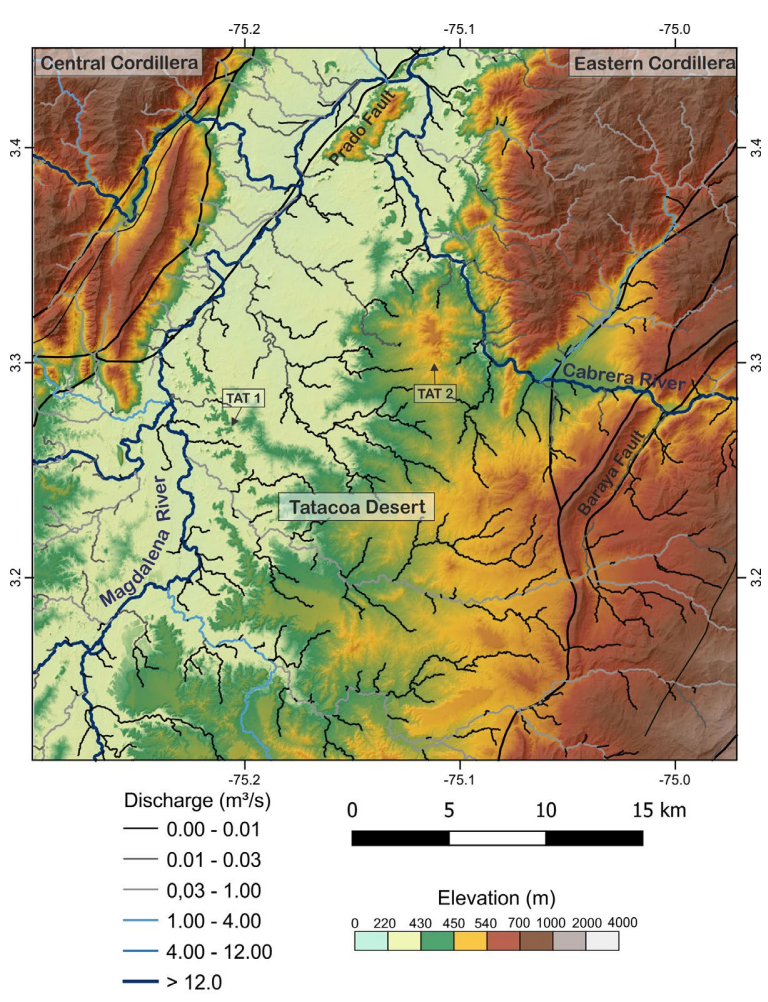

Figure 2. Topographic map of the Tatacoa Desert (TanDem-X, $12 \mathrm{~m}$ resolution). Discharge was calculated by considering the drainage area, the mean annual precipitation and the potential evapotranspiration index. 